\title{
Application of International Best Practice Guideline in Diabetic Ulcer Patients
}

\author{
Mayusef Sukmana*, Roni Sianturi, Muhammad Aminuddin \\ Mulawarman University, East Kalimantan, Indonesia \\ Corresponding author : 200801 sukmana@gmail.com
}

\begin{abstract}
Background: Diabetic ulcer is one of the complications of Diabetes mellitus. Assessment of diabetic ulcers is done as a basis in determining wound care and therapy provided so that it needs to know its characteristics.

Purpose: This study was to determine the characteristics of wounds assessment tools diabetic ulcer International Best Practice Guideline (IBPG) at Abdul Wahab Sjahranie Hospital Samarinda

Method: The study design was descriptive with a case study approach, the sampling technique was purposive sampling carried out in May 2019 with three respondents. The instrument used is the wound assessment tool International Best Practice Guideline which contains: sensation, callus, wound base, temperature and location.

Results: Respondents 1 experienced neuroiskemic injuries. Respondent 2 suffered neuropathic injuries and Respondent 3 had ischemic injury.

Conclusion: Characteristics of ulcers based on the International Best Practice Guidelines respectively, neuroiskemic, neuropathic and ischemic ulcers. Health workers are expected to apply a more detailed assessment of diabetic ulcers so that they can determine the appropriate treatment.
\end{abstract}

Keywords: Diabetic Ulcer, Wounds Assessment Tools, International Best Practice Guideline

How to Cite: Sukmana, M., Sianturi, R., \& Aminuddin, M. (2019). Application of International Best Practice Guideline in Diabetic Ulcer Patients. Journal Of Nursing Practice, 3(1), 50-62.

https://doi.org/10.30994/jnp.v3i1.65 


\section{Journal Of Nursing Practice}

http://thejnp.org

ISSN: 2614-3488 (print); 2614-3496 (online)

Vol.3 No.1. October 2019. Page.50-62

\section{BACKGROUND}

Diabetes mellitus is still a health problem in the world today, this disease is one of the health problems that are often experienced by people, and become a deadly disease in addition to cancer and heart attacks. Diabetes mellitus itself is defined as a group of metabolic diseases that have the characteristics of excess blood sugar levels or hyperglycemia that occurs due to abnormalities in insulin secretion or insulin action or both (PERKENI, 2015).

The prevalence of people with diabetes mellitus in Indonesia in 2007 is $(1,5 \%)$, $2013(2,1 \%)$ and $2018(2,0 \%)$. While the prevalence of diabetes mellitus in East Kalimantan in 2007 is (1,3\%), 2013 (2,7\%) dan 2018 (3,0\%) (Balitbang Kemenkes RI, 2018). The results of a preliminary study conducted by researchers on March 5, 2019 at Abdul Wahab Sjahranie Hospital in Samarinda, in 2018 there were as many as 1163 visits for diabetes mellitus cases. The highest number of visits was in the Inpatient Room of Flamboyan Room as much as 247 or $21.24 \%$ of the total visits. The majority of visits of patients suffering from Diabetes Mellitus based on these data were 646 or $55.55 \%$ women with age $>55$ years of 567 or $48.75 \%$. The majority of days of stay in the range of $0-10$ days were $878(75.49 \%)$ and the mortality rate due to Diabetes Mellitus was 147 or $12.64 \%$. In addition, there were 357 data on the incidence of diabetic ulcers. The majority of sufferers were 181 women $(50.7 \%)$ with age $>55$ years $143(40.06 \%)$. The highest incidence was in the Inpatient Installation of Flamboyan Room as many as 103 visits or $28.85 \%$ with a span of $0-10$ days treatment time of $218(61.06 \%)$. While the death rate that occurs due to diabetic ulcers is 36 or $10.08 \%$.

Diabetic ulcers are chronic injuries that commonly occur in the area below the ankle caused by peripheral neuropathy, peripheral arterial disease or both which increase morbidity, mortality and reduce the quality of life of patients (PERKENI, 2015). Characteristics of diabetic ulcers are neuropathy, ischemia and infection. According to the International Diabetes Federation divides the risk factors for diabetic ulcers into three namely; peripheral neuropathy, deformity and trauma or history of diabetic ulcer (Boulton et al., 2018) (Ibrahim Ammar, Jude Edwar, Langton Katia, Jesus M Fermin, Gawis Hanan, 2017). Long suffer from diabetes mellitus also affects the risk of injury. People with diabetes mellitus who are $>5$ years are 2 times more at risk of having an ulcer compared to patients who are $<5$ years old (Fitria et al., 2017).

Diabetic ulcers have a variety of forms so their characteristics need to be known. Assessment of wound characteristics using wound assessment tools, one of which is the International Best Practice Guideline, which divides diabetic ulcers into neuropathic, ischemic and neuroiskemic wounds. (Jain and Joshi, 2013).

Diabetic ulcer assessment is very important to predict the duration of healing, provide information about the condition of the wound so that it becomes the basis for determining the appropriate intervention (Yusuf, S., \& Tahir, 2018). Assessment of wounds is carried out to determine management such as the selection of the principle of wound dressing, based on the results of research conducted by Wahyuni (2016) at Prof. Dr. Soekandar Mojosari who applied the principle of moist wound healing or the principle of moist on the wound showed that all respondents (100\%) experienced wound regeneration after being treated for 7 days (Wahyuni, 2016). Another benefit that can be obtained from applying proper wound assessment is determining the cost of treatment. The cost of treating diabetic ulcers that have experienced gangrene is higher when compared to diabetic ulcers that are non-gangrene, which is Rp.386,790 for nongangrenous wounds and Rp.950,211 for gangrenous wounds (Sukmawati et al., 2016). 


\section{Journal Of Nursing Practice}

http://thejnp.org

ISSN: 2614-3488 (print); 2614-3496 (online)

Vol.3 No.1. October 2019. Page.50-62

Management of diabetic ulcers requires a multidisciplinary treatment team, therefore a proper assessment of the wound is very important as a team information in finding the cause of the wound. Assessing the size, depth, presentation and location of the wound will help underlie selection and develop therapies and monitor various patient responses for intervention (Chadwick P, Edmonds M, McCardle J, 2013).

\section{OBJECTIVE}

This study aimed to find out how the characteristics of diabetic ulcers according to IBPG whose benefits can help the selection of appropriate and efficient wound care. Appropriate treatment will provide many benefits, a short treatment period, improved wound healing, to reduce treatment costs. Conversely, if not applying appropriate assessment and treatment allows for the emergence of various problems and even worsen the condition of the wound, so it needs to be appointed descriptive research on "Application of IBPG in patients with diabetic ulcers". In other words, the main focus of this study is to determine the characteristics of diabetic ulcers based on the wound assessment tools of the International Best Practice Guideline.

\section{METHODS}

The design used is descriptive with a case study approach through direct observation which results in general respondent characteristics and diabetic ulcer characteristics. The study was conducted in May 2019 at the Flamboyant Inpatient Installation of Abdul Wahab Sjahranie Hospital Samarinda, East Kalimantan.

The samples examined with the inclusion criteria in this study were as follows patients with diabetic wounds (Diabetic Ulcer) who were treated at Abdul Wahab Sjahranie Hospital Samarinda, aged over 18 years. The exclusion criteria was a decrease in consciousness. The sampling technique uses purposive sampling. The instrument used was the International Best Practice Guideline wound assessment tool which contained: sensation, callus, wound base, temperature and location (tabel 1, 2, 3).

The participants were assured that their engagement was voluntary, and that anonymity, privacy, and confidentiality of the data were guaranteed. Furthermore, they were informed about the purpose and the method of the study before signing a written informed consent. The questionnaires were distributed to eligible participants at the Abdul Wahab Sjahranie Hospital, and respondents were asked to complete and return them in the same time

\section{RESULT}

The study was conducted by direct observation using wound observation sheets containing wound characteristics according to the International Best Practice Guideline.

\section{Characteristics of Respondents}

Respondent 1 (R1), 50-year-old woman, Islam, Banjar tribe, elementary school (SD) education, employment as a farmer. The length of treatment that has been undertaken for 2 days, a history of suffering from diabetes mellitus for 5 years. Family history of diabetes mellitus and hypertension. History of wounds 1 week, the first time suffered injuries around May 5, 2019. Injuries occur due to the use of shoes when working in the garden using shoes do not use socks so that the toes blister and are left to develop into ulcers. 60 $\mathrm{kg}$ body weight and $155 \mathrm{~cm}$ height. The Ankle Brakhial Pressure Index (ABPI) value is 1.16 , the blood glucose value is $70 \mathrm{mg} / \mathrm{dL}$. Diabetic ulcer on metatarsal digiti 5 with a size of about $2 \mathrm{~cm}$, the wound smelled with moderate fluid. Treatment was given 
Ceftriaxone 1gr / 12 hours IV, Omeprazole 40mg / 12 hours IV, Metoclorpramide 50mg / 8 hours IV and Insulin Apidra 4 units / 8 hours SC. High-calorie high-protein porridge diet is given three times per day. Wound care is carried out by the method of moist (moist) with $0.9 \% \mathrm{NaCl}$ dressing and wrapped with gauze and hypapix plaster.

Respondent 2 (R2), 36-year-old woman, Muslim, Madurese, primary education, private occupation. The duration of treatment is 1 month. Suffering from diabetes mellitus 1 year, first known in 2018. Family history of diabetes mellitus. Long suffered a wound of approximately 1 month, the wound initially occurred when the respondent walked barefoot and scratched nails on the sole of the foot and eventually developed into a diabetic ulcer. Weight $55 \mathrm{~kg}$ and height $162 \mathrm{~cm}$. ABPI value of 1.0 and blood glucose value at $143 \mathrm{mg} /$ $\mathrm{dL}$. The wound is $10 \mathrm{~cm}$ long and $3 \mathrm{~cm}$ wide with minimal wound odor and minimal yellowish wound fluid. Treatment is given Ceftriaxone injection $1 \mathrm{gr} / 12$ hours IV, Metoclorpramide 50mg / 8 hours IV, Lanzoprazole 500mg / 24 hours IV and Novorapid Insulin 12 units / 8 hours. High calorie diets high in protein three times per day. Wound care uses $0.9 \% \mathrm{NaCl}$ dressing with gauze and hypapix tape.

Respondent 3 (R3), 53-year-old male, Muslim, Kutai ethnic with elementary school education, work as a farmer. Duration of treatment for 3 weeks. History of the disease first diabetes mellitus 9 years ago. The family has no family history of diabetes mellitus. The history of the wound was experienced since April 2019, the wound was caused by not using footwear while on the move and tripping over a stone on the heel of the foot. Weight $45 \mathrm{~kg}$ and height $160 \mathrm{~cm}$. ABPI value of 1.09 , blood glucose at $104 \mathrm{mg} / \mathrm{dL}$. Wounds measuring $4 \mathrm{~cm}$ long and $6 \mathrm{~cm}$ wide, minimal wound odor with minimal hemoserous fluid. The treatment is given an injection of Meropenem 1gr / 8 hours IV, Omeprazole 1gr / 24 hours IV and Novorapid insulin 8 units / 8 hours. High calorie diets high in protein three times a day. Wound care with $0.9 \% \mathrm{NaCl}$ dressing and gauze with elastic bandages.

\section{Characteristics of diabetic ulcers according to IBPG}

$\mathrm{R} 1$ is a neuroiskemic wound, which is characterized by some of the characteristics listed in Table 1. The assessment of the wound is as follows: There is a decrease in sensational ability characterized by loss of sensitivity at 9 of the 10 points tested with $10 \mathrm{~g}$ monofilament, there is necrosis of metatarsal digiti 5, the basis black sores or having poor granulation tissue, cold foot temperature and weak palpable pulses, the location of injuries to the toes (Figure 1). 
Table 1. Characteristics of diabetic ulcer according to IBPG respondent 1 at A. Wahab Sjahranie Hospital Samarinda in May 2019

\begin{tabular}{|c|c|c|c|}
\hline Characteristics & Neuropathy & Ischemic & Neuroiskemic \\
\hline $\begin{array}{l}\text { Feeling / } \\
\text { sensation }\end{array}$ & Loss of taste ability & $\begin{array}{l}\text { Feeling pain (not } \\
\text { losing feelings) }\end{array}$ & Decreased taste ability \\
\hline $\begin{array}{l}\text { Callus and } \\
\text { necrosis }\end{array}$ & $\begin{array}{l}\text { Callus, and } \\
\text { usually thick }\end{array}$ & Generally necrosis & $\begin{array}{l}\text { There is minimal } \\
\text { callus and necrosis }\end{array}$ \\
\hline Wound Base & $\begin{array}{l}\text { The granulated pink } \\
\text { is surrounded by } \\
\text { callus }\end{array}$ & $\begin{array}{l}\text { Pale, yellow with its } \\
\text { granulation tissue } \\
\text { bad }\end{array}$ & $\begin{array}{l}\text { Poor granulation } \\
\text { tissue }\end{array}$ \\
\hline $\begin{array}{l}\text { Foot } \\
\text { temperature } \\
\text { and pulse }\end{array}$ & $\begin{array}{l}\text { Warm with palpable } \\
\text { pulses }\end{array}$ & $\begin{array}{l}\text { Cold and no pulse / } \\
\text { weakening }\end{array}$ & $\begin{array}{l}\text { Cold, no pulse / } \\
\text { weakened }\end{array}$ \\
\hline $\begin{array}{l}\text { Location in } \\
\text { general }\end{array}$ & $\begin{array}{l}\text { In areas that hold } \\
\text { heavy loads such as } \\
\text { the metatarsal head, } \\
\text { heels and dorsum of } \\
\text { the toes }\end{array}$ & $\begin{array}{l}\text { Fingertips, the edge } \\
\text { of the nail and } \\
\text { between the fingers } \\
\text { and the lateral edge } \\
\text { of the foot }\end{array}$ & $\begin{array}{l}\text { Edges of toes and } \\
\text { fingers }\end{array}$ \\
\hline
\end{tabular}

$\mathrm{R} 2$ is a neuropathic wound, which is characterized by some of the characteristics listed in table. 2 The assessment of the wound is loss of sensation ability, thick callus, pink wound base surrounded by callus and there is slough, palpable feet and weak pulse and the location of the wound in the area soles of the feet (Figure 2).

Table 2. Characteristics of diabetic ulcers according to IBPG respondent 2 at A. Wahab Sjahranie Hospital Samarinda in May 2019

\begin{tabular}{|c|c|c|c|}
\hline Characteristics & Neuropathy & Ischemic & Neuroiskemic \\
\hline $\begin{array}{l}\text { Feeling / } \\
\text { sensation }\end{array}$ & Loss of taste ability & $\begin{array}{l}\text { Feeling pain (not } \\
\text { losing feelings) }\end{array}$ & $\begin{array}{l}\text { Decreased taste } \\
\text { ability }\end{array}$ \\
\hline $\begin{array}{l}\text { Callus and } \\
\text { necrosis }\end{array}$ & $\begin{array}{l}\text { Callus, and usually } \\
\text { thick }\end{array}$ & & $\begin{array}{l}\text { There is minimal } \\
\text { callus and necrosis }\end{array}$ \\
\hline Wound Base & $\begin{array}{l}\text { The granulated } \\
\text { pink is surrounded } \\
\text { by callus }\end{array}$ & & $\begin{array}{l}\text { Poor granulation } \\
\text { tissue }\end{array}$ \\
\hline $\begin{array}{l}\text { Foot } \\
\text { temperature } \\
\text { and pulse }\end{array}$ & $\begin{array}{l}\text { Warm with } \\
\text { palpable pulses }\end{array}$ & $\begin{array}{l}\text { Cold and no pulse / } \\
\text { weakening }\end{array}$ & Usually necrosis \\
\hline $\begin{array}{l}\text { Location in } \\
\text { general }\end{array}$ & $\begin{array}{l}\text { Pada area yang } \\
\text { menahan beban } \\
\text { berat seperti kepala } \\
\text { metatarsal, tumit } \\
\text { dan bagian dorsum } \\
\text { dari jari } \\
\text { kaki }\end{array}$ & $\begin{array}{l}\text { Fingertips, the edge } \\
\text { of the nail and } \\
\text { between the fingers } \\
\text { and the lateral edge } \\
\text { of the foot }\end{array}$ & $\begin{array}{l}\text { Pale, yellow with } \\
\text { poor granulation } \\
\text { tissue }\end{array}$ \\
\hline
\end{tabular}




\section{Journal Of Nursing Practice}

http://thejnp.org

$\mathrm{R} 3$ is an ischemic wound, which is characterized by several characteristics listed in table. 3 The assessment of the wound has decreased / lost the ability to sensation, can still feel pain when the wound is touched and when treated, there is necrosis and slough tissue, the wound base shows red but surrounded by slough tissue, the foot is generally cold and the pulses are weak, the location of the wound is lateral to the foot to the bottom. (Figure $3)$.

Table 3. Characteristics of diabetic ulcers according to IBPG respondents 3 at A. Wahab Sjahranie Hospital Samarinda in May 2019

\begin{tabular}{|c|c|c|c|}
\hline Characteristics & Neuropathy & Ischemic & Neuroiskemic \\
\hline $\begin{array}{l}\text { Feeling / } \\
\text { sensation }\end{array}$ & Loss of taste ability & $\begin{array}{l}\text { Feeling pain (not } \\
\text { losing feelings) }\end{array}$ & $\begin{array}{l}\text { Decreased taste } \\
\text { ability }\end{array}$ \\
\hline $\begin{array}{l}\text { Callus and } \\
\text { necrosis }\end{array}$ & $\begin{array}{l}\text { Callus, and usually } \\
\text { thick }\end{array}$ & Usually necrosis & $\begin{array}{l}\text { There is minimal } \\
\text { callus and necrosis }\end{array}$ \\
\hline Wound Base & $\begin{array}{l}\text { The granulated } \\
\text { pink is surrounded } \\
\text { by callus }\end{array}$ & $\begin{array}{l}\text { Pale, yellow } \\
\text { with poor } \\
\text { granulation } \\
\text { tissue }\end{array}$ & $\begin{array}{l}\text { Poor granulation } \\
\text { tissue }\end{array}$ \\
\hline $\begin{array}{l}\text { Foot } \\
\text { temperature } \\
\text { and pulse }\end{array}$ & $\begin{array}{l}\text { Warm with } \\
\text { palpable pulses }\end{array}$ & $\begin{array}{l}\text { Cold and no pulse / } \\
\text { weakening }\end{array}$ & $\begin{array}{l}\text { Cold, no pulse / } \\
\text { weakened }\end{array}$ \\
\hline $\begin{array}{l}\text { Location in } \\
\text { general }\end{array}$ & $\begin{array}{l}\text { In areas that hold } \\
\text { heavy loads such as } \\
\text { the metatarsal head, } \\
\text { heels and dorsum of } \\
\text { the toes }\end{array}$ & $\begin{array}{l}\text { Fingertips, the } \\
\text { edge of the nail } \\
\text { and between the } \\
\text { fingers and the } \\
\text { lateral edge of } \\
\text { the foot }\end{array}$ & $\begin{array}{l}\text { Edges of toes and } \\
\text { fingers }\end{array}$ \\
\hline
\end{tabular}
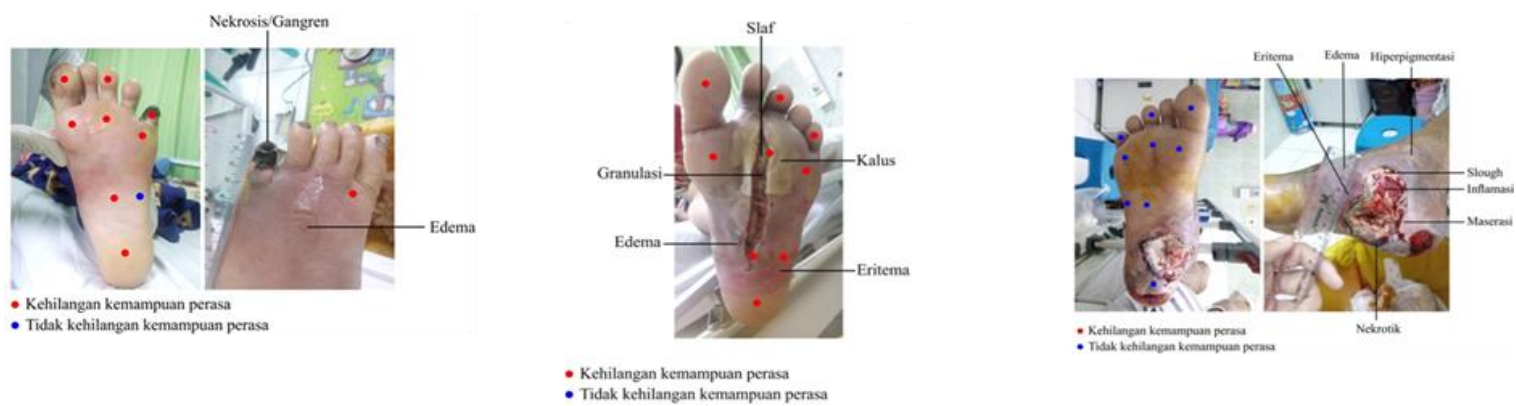

Figure 1. R1 diabetic ulcer Figure 2. Diabetic ulcer R2 Figure 3. Diabetic ulcer R3

\section{DISCUSSION}

\section{Characteristics of Respondents}

Respondents numbered three people with the sex of the respondents two women and one man. Diabetes mellitus is more common in women than in men (PERKENI, 2015). Women tend to have high levels of fat that affect the work of insulin (PERKENI, 2015). These results are in line with observational studies conducted by Fitria in Dr. Zainal Abidin Hospital and Meuraxa Hospital in Banda Aceh in 2017, stating that 31 out of 57 respondents $(54.4 \%)$ were women (Fitria et al., 2017) therefore complications diabetes 


\section{Journal Of Nursing Practice}

http://thejnp.org

ISSN: 2614-3488 (print); 2614-3496 (online)

Vol.3 No.1. October 2019. Page.50-62

mellitus such as diabetic ulcer is also more common in women than in men.

Respondents' ages are 50, 36 and 53 years, meaning that 2 out of 3 respondents have $\geq 50$ years of age. Age is a risk factor for diabetes mellitus and diabetic ulcers. Organs in the elderly experience decreased function, such as insulin resistance which causes instability and even an increase in uncontrolled blood sugar levels that can cause various complications of diabetes mellitus such as reduced vision, decreased sensation due to diabetes neuropathy increases the incidence of unconscious ulcers which in the end developed into diabetic ulcers (PERKENI, 2015). Research conducted by Jelantik in 2013 showed that 45 people out of 50 respondents (90\%) with diabetes mellitus were aged berada40 years (Jelantik and Haryati, 2014). The results of research by Fitria in 2017 the incidence of diabetic ulcers was more found in patients with an age range of 56-65 years (Fitria et al., 2017).

The average education of respondents is primary school, the level of education affects the level of understanding of a person in receiving information. People with a high level of education usually know more about disease or health information so that they have a high awareness about health. Conversely people with low levels of education have low knowledge about health so that it affects awareness in maintaining health. Research conducted by Hardianti in 2018 states that low education affects the level of knowledge of respondents about the prevention of diabetic ulcers and their care (Hardianti, 2018).

Education also affects the type of respondent's work, the research results found that 2 respondents worked as farmers and 1 respondent as a private worker. Work activities such as farming are very risky for ulcers. The results of the interview respondents said that they sustained injuries while doing their work, namely when farming, R1 suffered injuries due to the use of narrow footwear, namely boots which cause blisters on the toes that develop into diabetic ulcers. R2 suffered injuries due to nails scratched on the sole of the foot when walking barefoot, R3 who also worked as a farmer suffered injuries due to being stepped on a stone on the heel of the wound initially left alone eventually became diabetic ulcers. The type of work is a risk factor that can result in trauma to the foot that can become diabetic ulcers.

The length of suffering from diabetes mellitus is a risk factor for injury, in this case study it was found that the long history of suffering from diabetes mellitus at R1 was 5 years, R2 for 1 year and R3 9 years. These results indicate that 2 out of 3 respondents have diabetes mellitus $\geq 5$ years, this is in accordance with research conducted by Roza et al., 2015 which states that as many as 20 out of 39 respondents $(63.7 \%)$ of diabetic ulcer sufferers have a history of suffering from diabetes mellitus during $\geq 5$ years (Loviana, Rudy and Zulkarnain, 2015). People with diabetes mellitus who are $\geq 5$ years of age are twice as likely to have diabetic ulcers compared to patients who are $\leq 5$ years old (Fitria et al., 2017). The length of suffering from diabetes mellitus is likely to experience chronic hyperglycemia the greater the eventual cause complications such as retinopathy, neuropathy and diabetic ulcers (Loviana, Rudy and Zulkarnain, 2015).

Family history is a factor that influences the occurrence of diabetes mellitus and its complications, of the three respondents who have a family history of diabetes mellitus are R2, R1 has a history of high fat / cholesterol and hypertension while R3 has no family history of the disease.

Family history of diabetes mellitus is a genetic or hereditary risk factor that causes a person to have diabetes mellitus (PERKENI, 2015). Research conducted (Jelantik and Haryati, 2014) found that 44 out of 50 respondents $(88 \%)$ with diabetes mellitus had a history of hypertension and found a significant relationship between hypertension and 


\section{Journal Of Nursing Practice}

http://thejnp.org

ISSN: 2614-3488 (print); 2614-3496 (online)

Vol.3 No.1. October 2019. Page.50-62

diabetes mellitus.

Hypertension causes damage to blood vessel endothelium causing platelet aggregation which can result in vascular deficiency resulting in ischemia in tissues that can cause diabetic ulcers (Hardianti, 2018). Increased peripheral resistance due to the attachment of cholesterol to the walls of blood vessels will increase the work of the heart, hypertension will occur and disrupt peripheral vascularization which leads to reduced oxygen circulation in the legs and ulcers occur. (Setiati, 2014).

The ABPI values obtained at the time of the assessment were R1 1.16, R2 1.0 and $\mathrm{R} 3$ 1.09. ABPI is measured by using vascular dopler to assess arterial insufficiency. ABPI is the ratio between systolic blood pressure of the foot (ankle) and systolic blood pressure in the arm (brachiallis). Under normal circumstances systolic pressure on the legs and arms is the same or a little higher (Sari Y, 2015). In the results of the study, the ABPI value of the respondents was within the normal range which meant there were no vascular disorders. ABPI values $<0.9$ indicate peripheral arterial disease or PAD which can increase the incidence and severity of diabetic ulcers (Christian, Sumumpang and Limpeleh, 2015).

The results of blood sugar when respondents obtained at the time of assessment are as follows R1 $70 \mathrm{mg} / \mathrm{dL}, \mathrm{R} 2144 \mathrm{mg} / \mathrm{dL}$ and R3 $104 \mathrm{mg} / \mathrm{dL}$, these results indicate that the average respondent has low blood sugar levels. This might occur due to lack of intake after being given insulin therapy so that blood sugar levels become low (Ernawati, 2013). The results of the study of wounds generally found that R1 had a wound size of about 2 $\mathrm{cm}$ with smelling wounds due to localized gangrene of the metatarsal digiti 5 with a medium yellowish wound fluid and edema of the feet. R2 with a wound size of $10 \times 3 \mathrm{Cm}$ with a minimum odor and a minimal yellowish wound fluid, while R3 has a wound size of $4 \times 6 \mathrm{Cm}$ with a minimum odor and hemoserous wound fluid or mixed with blood.

The size of the wound in the respondent is affected by the formation of an abscess or edema that causes surgery or incision in the wound to be done so that the fluid in the wound can be released and to improve the condition and healing of the wound. Wound odor is found in wounds with a black base or that has become gangrene that starts from necrotic tissue.

This occurs due to reduced or inadequate blood supply to the tissues either due to injury, radiation or chemicals that are compounded by bacterial infections. Wound odor is influenced by the process of infection and the result of protein products so that wound management is needed that can minimize wound odor for patient comfort and the surrounding environment. Yellow wound fluid indicates an infection of this fluid commonly referred to as a type of purulent exudate that can be yellow, gray or green, while the fluid mixed with blood is called hemoserous indicating damage to the capillaries or infection that has already affected the capillaries, causing blood leakage (Mary Greece, 2015).

The duration of treatment carried out by respondents which was calculated at the time of the assessment on May 12, 2019 was at R1 for 2 days of treatment, R2 for 1 month of treatment and R3 for 3 weeks of treatment. The data is withdrawn for a long interval of treatment, which is 2 days - 30 days. This result is in line with research conducted by Sukmawati et al in 2016 stating that the average length of treatment for nongangrene ulcers is 27.3 days while for gangrene ulcers 91.8 days. The length of treatment for diabetic ulcers depends on the type of ulcer, the etiology of the ulcer and the type of treatment given (Sukmawati et al., 2016).

Type of treatment while in hospital R1 and R2 get ceftriaxone antibiotic injection 


\section{Journal Of Nursing Practice}

http://thejnp.org

ISSN: 2614-3488 (print); 2614-3496 (online)

Vol.3 No.1. October 2019. Page.50-62

therapy. Cetriaxone is an antibiotic that works to inhibit bacterial cell wall synthesis and is more effective in gram-negative bacteria (Yelly Oktavia Sari, Dedy Almasdy, 2018). The administration of ceftriaxone antibiotics is a type of empirical therapy that is the use of antibiotics in cases of infection that have no known type of bacteria, the purpose of giving empirical therapy is an effort to prevent the development of bacteria suspected of causing infection (RI Ministry of Health, 2011).

In R3, meropenem antibiotic injection therapy is used. Meropenem is an antibiotic that works widely against various types of bacteria, both gram negative, gram positive and anaerobic which are the most causes of infection (Ministry of Health Republic of Indonesia, 2011). Research by Agistia in 2017 states that meropenem has a high sensitivity to bacteria (Agistia, Mukhtar and Nasif, 2017). The selection of meropenem antibiotics is the definitive therapy or therapy given after the bacteria is known (Ministry of Health Republic of Indonesia, 2011). The results of this case study differ from the research conducted by Sari in 2018 which stated that the pattern of antibiotic administration in diabetic ulcers was at most a combination of ceftriaxone and metronidazole as much as $26.1 \%$ (Yelly Oktavia Sari, Dedy Almasdy, 2018).

Determination of diet must be done in accordance with the calorie requirements in this case study, the body mass index of each respondent was $\mathrm{R} 1,155 \mathrm{Cm}$, height $60 \mathrm{~kg}$, BMI 24.9 included in the risk category, R2, $162 \mathrm{Cm}$, weight $55 \mathrm{~kg}$, BMI 20.9 normal and R3 $160 \mathrm{~cm}$ height, body weight $45 \mathrm{~kg}$, BMI 17.5 which is included in the category of underweight. The diet conducted by all respondents during treatment was a high-calorie, high-protein porridge. The main purpose of implementing diet for diabetics is to reduce hyperglycemia, prevent hypoglycemia in patients receiving insulin treatment and reduce the risk of cardiovascular complications (Ernawati, 2013).

The type of wound care received by all respondents was sterile gauze dressing moistened with $0.9 \% \mathrm{NaCl}$. Wound care with the concept of moist or moist wound healing is to maintain the condition of the wound remains in a moist state that facilitates the movement of cells at the base of the wound and allows neutrophils and macrophages to migrate better (Wahyuni, 2016). The moist wound healing treatment conducted by Wahyuni (2016) in his research on the effect of the moist wound healing technique showed that 20 respondents $(100 \%)$ had regenerated wounds after being treated for 7 days. Before dressing the wound with a $\mathrm{NaCl} 0.9 \%$ moist gauze dressing wound was first washed with $0.9 \% \mathrm{NaCl}$ wound washing fluid. $\mathrm{NaCl} 0.9 \%$ wound washing solution is one of the recommended washing fluid solutions because it is non-damaging to tissue and isotonic to the body so it is safe for granulation tissue (Maryunani, 2015).

\section{Characteristics of diabetic ulcers}

R1 based on Characteristics of the International Best Practice Guideline is including neuroisemic wounds with ulcer assessment results according to the following characteristics: Feelings / sensations, R1 has decreased sensation ability in the legs, this is evidenced by the results of the assessment using a $10 \mathrm{~g}$ monofilament which shows no sensation of 9 out of 10 points tested. R1 only feels one point, which is the lateral part of the foot.

There is tissue necrosis which is characterized by the presence of gangrene ulcers with poor granulation tissue. The palpable pulses are weak when touched and the feet tend to be cold while the location of ulcers on the toes is a characteristic of neuroiskemic injuries. Neuroiskemic ulcers are a combination of the etiology of neuropathy and ischemic ulcers. Neuropathy is a microvascular complication of diabetes mellitus that occurs due to 


\section{Journal Of Nursing Practice}

http://thejnp.org

ISSN: 2614-3488 (print); 2614-3496 (online)

Vol.3 No.1. October 2019. Page.50-62

uncontrolled blood sugar or hyperglycemia (Ernawati, 2013).

The state of hyperglycemia triggers an increase in the metabolism of the polyol pathway resulting in the deposition of sorbitol and fructose in the peripheral nerves which causes disruption of nerve implants. Besides neuropathy is also caused by vascular disorders resulting from vascular autonomic nerve disorders that affect sensory neuropathy in the form of loss of sensation in the legs, whereas in motor neuropathy causes atrophy of the intrinsic muscles of the foot, causing contractures and deformities in the legs that increase the incidence of ulcers diabetikum (Suriadi, 2015). According to research conducted by Armstrong et al. in 2011 stated that the prevalence of neuroisemic wounds was $50 \%$ of the incidence of diabetic ulcers (Chadwick P, Edmonds M, McCardle J, 2013). While the results of research conducted by Christia et al. in 2015, 31 out of 100 respondents $(31 \%)$ experienced neuroiskemic ulcers (Christia, Yuwono and Fakhrurrazy, 2015).

R1 ulcers experienced by the presence of necrotic tissue in the metatarsal digiti 5 with the basic color of a black wound / gangrene that indicates poor tissue injury. Gangrene is caused by vascular disruption in blood vessels which causes blood supply to decrease or stop. In R1, ABPI 1.1 results are obtained, which means there are no vascular or atherosclerotic disorders, so gangrene that occurs is likely a result of metabolic disorders due to uncontrolled blood glucose levels. This is supported by a history of R1 who has diabetes mellitus for 5 years and has a family history of diabetes mellitus, coupled with the presence of bacterial infections that aggravate diabetic ulcers (Maryunani, 2015). R1 has decreased sensation and numbness so that the foot temperature is generally felt cold with the location of the ulcer located on the finger which is characteristic of neuroiskemic ulcers.

R2 had a neuropathic ulcer characterized by loss of taste ability at 10 points tested with $10 \mathrm{~g}$ monofilament. neuropathy is caused by a state of hyperglycemia that triggers metabolic abnormalities and also by vascular abnormalities that are caused which will ultimately reduce the sensation in people with diabetes mellitus, foot deformities that increase the incidence of diabetic ulcers (Maryunani, 2015)(Suriadi, 2015).

Formation of thick callus on ulcer R2 caused by excessive pressure on the plantar legs, callus or also known as hyperkeratinocytes can be formed due to hardened wound edges, this callus formation will inhibit the contraction of wound edges (Suriadi, 2015). According to research conducted by Edmonds and Foster in 2006, callus in neuropathic ulcers should be eliminated because it can suppress the wound underneath as a result of the formation of new wounds, inflammation and bleeding under the callus that can cause tissue death or necrotic (Edmonds, ME, \& Foster, 2006).

The base of the R2 wound is pink which indicates granulation, but is surrounded by a callus that can inhibit the growth of new tissue (Edmonds, M. E., \& Foster, 2006). Although including neuropathic ulcers, in R2, cold feet temperature with weak pulse such as ischemic or neuroischemic wounds is obtained. Neuropathic complications have two categories, sensory neuropathy which decreases pain sensation, leg temperature and taste ability, while motor neuropathy results in deformity in the legs which increases the risk of trauma. Another factor that causes the respondent's feet to cool down is the length of time suffering from diabetic ulcers which can increase the risk of peripheral arterial disease so that neuropathy wounds can become ischemic injuries (Boulton et al., 2018).

The injury occurred in the plantar part of the foot which holds the load, caused by trauma affected by nails that scratch the soles of the feet unnoticed by respondents who developed into diabetic ulcers, this occurs because in patients with neuropathy there has been loss of taste ability. Neuropathic injuries have a high incidence of diabetes mellitus 


\section{Journal Of Nursing Practice}

http://thejnp.org

ISSN: 2614-3488 (print); 2614-3496 (online)

Vol.3 No.1. October 2019. Page.50-62

in 35\% (Armstrong, D. G., Boulton, A. J. M., \& Bus, 2017).

In R3, the results of ischemic ulcers without loss of taste and still feeling pain, the results of sensation testing with $10 \mathrm{~g}$ monofilament respondents were able to feel sensations. The cause of ischemic ulcer is an indication of peripheral arterial disease that is started by increasing blood glucose levels which causes hardening and even damage to arteries and capillaries (Maryunani, 2015). Poor blood sugar control is a cause of Peripheral Arterial Disease (PAD) (Lepantalo, M., Apelqvist, J., Setaccie, C., Riccof and Donato, G. de, Becker, F., ... Davies, 2011).

In addition, poor peripheral vascularization also causes inhibition of wound healing due to oxygen and nutrients needed so that tissue necrosis or death is marked by the presence of sloughs or black sores (Chadwick P, Edmonds M, McCardle J, 2013). Weakened pulses and cold tendencies are the result of inadequate peripheral vascularization with a characteristic wound position that occurs on the lateral edge of the foot, the incidence of ischemic injury itself is $15 \%$ of the incidence of diabetic ulcers (Amstrong, D. G., Boulton, A. J. M., \& Bus, 2017).

\section{CONCLUSION}

Characteristics of respondents in this study were 2 women and 1 man, with the age of each respondent 50, 36 and 53 years, the last education was elementary school, 2 respondents worked as farmers, and 1 as a private worker. A history of diabetes mellitus of an average of $\geq 5$ years and a history of diabetic ulcers in the treatment range of 2-30 days.

Characteristics of diabetic ulcers based on the International Best Practice Guidline (2013), R1 is neuroiscemic ulcers, R2 with neuropathic ulcers and R3 with ischemic ulcers.

The characteristics of diabetic ulcers International Best Practice Guidline (2013) can be taught in more depth as an additional reference for wound assessment. Health agencies should prepare a variety of wound assessment instruments that are complete so that it can be applied by existing health workers in dealing with diabetic ulcers.

\section{REFERENCE}

Agistia, N., Mukhtar, H. and Nasif, H. (2017) 'Efektifitas Antibiotik pada Pasien Ulkus Kaki Diabetik', Jurnal Sains Farmasi \& Klinis, 4(1), p. 43. doi: 10.29208/jsfk.2017.4.1.144.

Amstrong, D. G., Boulton, A. J. M., \& Bus, S. A. (2017) 'Diabetic foot ulcers and their recurrence', The New England Journal of Medicine. The New England Journal of Medicine, 376(24), pp. 2367-2375. doi: 10.1056/NEJMra1615439.

Balitbang Kemenkes RI (2018) 'Riset kesehatan dasar.' Jakarta: Riskesdas.

Boulton, A. J. M. et al. (2018) '2018 CONTRIBUTING AUTHORS Diabetic Foot Complications.' https://professional.diabetes.org/sites/professional.diabetes.org/files/media/foot_co mplications_monograph.pdf. 


\section{Journal Of Nursing Practice}

http://thejnp.org

ISSN: 2614-3488 (print); 2614-3496 (online)

Vol.3 No.1. October 2019. Page.50-62

Chadwick P, Edmonds M, McCardle J, A. D. (2013) 'International Best Practice Guidelines: Wound Management in Diabetic Foot Ulcers', in Wounds International. London: Wounds International,. Available at: http://www.woundsinternational.com/clinical-guidelines/best-practice-guidelineswound-management-in-diabetic-foot-ulcers.

Christia, S., Yuwono, A. and Fakhrurrazy (2015) 'Ulkus Diabetik Di Poliklinik Kaki Diabetik', Berkala Kedokteran, 11(No.1), pp. 25-32.

Edmonds, M. E., \& Foster, A. V. M. (2006) 'Diabetic foot ulcers neuropathic foot ulcer neuroischaemic foot ulcer.', $B M J, 332(1)$, pp. 407-410.

Ernawati (2013) Penatalaksanaan keperawatan diabetes melitus terpadu. Jakarta: Mitra Wacana Media.

Fitria, E. et al. (2017) 'Karakteristik Ulkus Diabetikum pada Penderita Diabetes Mellitus di RSUD dr. Zainal Abidin dan RSUD Meuraxa Banda Aceh', Buletin Penelitian Kesehatan, 45(3), pp. 153-160. doi: 10.22435/bpk.v45i3.6818.153-160.

Hardianti, D. (2018) 'DESCRIPTION OF FACTORS RELATED TO SEVERITY OF DIABETIC MELLITUS PATIENT TYPE 2 (Study in RSUD Kota Semarang)', Jurnal Kesehatan Masyarakat, 6, pp. 132-141. Available at: http://ejournal3.undip.ac.id/index.php/jkm.

Ibrahim Ammar, Jude Edwar, Langton Katia, Jesus M Fermin, Gawis Hanan, H. Y. Y. (2017) Idf Foot Care Recommendation. Brussels: The International Diabetes Federation.

Jain, A. and Joshi, S. (2013) 'Diabetic Foot Classifications: Review of Literature', Medicine Science | International Medical Journal, 2(3), p. 715. doi: 10.5455/medscience.2013.02.8069.

Jelantik, I. G. M. G. and Haryati, E. (2014) 'Hubungan Faktor Risiko Umur, Jenis Kelamin, Kegemukan dan Hipertensi dengan Kejadian Diabetes Melitus Tipe II di Wilayah Kerja Puskesmas Mataram', Media Bina Ilmiah39, 8(1), pp. 39-44. Available at: http://www.lpsdimataram.com/phocadownload/Februari-2014/7hubungan faktor risiko umur jenis kelamin kegemukan-jelantik haryati.pdf.

Kemenkes RI (2011) 'Pedoman umum penggunaan antibiotik.' Jakarta: Kementrian Kesehatan Republik Indonesia.

Kristiani, A. L., Sumangkut, R. M. and Limpeleh, H. P. (2015) 'Hubungan Ankle Brachial Index Dengan Keparahan Ulkus Pada Penderita Kaki Diabetik', Jurnal Biomedik (JBM), 7(3), pp. 171-177.

Lepantalo, M., Apelqvist, J., Setaccie, C., Riccof, J.-B. and Donato, G. de, Becker, F.,... Davies, A. H. (2011) 'Diabetic foot', in 42(S2), pp. 60-74. 


\section{Journal Of Nursing Practice}

http://thejnp.org

ISSN: 2614-3488 (print); 2614-3496 (online)

Vol.3 No.1. October 2019. Page.50-62

Loviana, R. R., Rudy, A. and Zulkarnain, E. (2015) 'Artikel Penelitian Faktor Risiko Terjadinya Ulkus Diabetikum pada Pasien Diabetes Mellitus yang Dirawat Jalan dan Inap di RSUP Dr . M .’, Jurnal Kesehatan Andalas, 4(1), pp. 243-248.

Maryunani (2015) Maryunan2015. Jakarta: In Media.

PERKENI (2015) Indonesia, P. E. (2015). Pengelolaan dan Pencegahan Diabetes Melitus Tipe 2 di Indonesia. PB. PERKENI.

Sari Y (2015) 'Perawatan luka diabetes berdasarkan konsep manajemen luka modern dan penelitian terkini.' Yogyakarta: Graha Ilmu.

Setiati (2014) Buku ajar ilmu penyakit dalam (Jilid II,). Jakarta: Interna Publishing.

Sukmawati et al. (2016) 'Analisa beban biaya dan waktu perawatan luka kaki diabetik (LKD) gangren unit pelayanan home care: retrospective cohort study', Jurnal Luka Indonesia, 2(1), pp. 65-70.

Suriadi (2015) Pengkajian Luka \& Penanganannya. Jakarta: Sagung Seto.

Wahyuni, L. (2016) 'Effect Moist Wound Healing Technique Toward Diabetes Mellitus Patients with Ulkus Diabetikum in Dhoho Room RSUD Prof Dr . Soekandar Mojosari', STIKES Bina Sehat PPNI Mojokerto, pp. 1-7.

Yelly Oktavia Sari, Dedy Almasdy, \& A. F. (2018) 'Evaluasi Penggunaan Antibiotik Pada Pasien Ulkus Diabetikum di Instalasi Rawat Inap ( IRNA )', Jurnal Sains Farmasi \& Klinis, 5(2), pp. 31-40.

Yusuf, S., \& Tahir, T. (2018) 'Study literatur : pengkajian luka kaki diabetes', Jurnal Luka Indonesia, 4(2), pp. 123-137. 